\title{
Dante and the Protestant Principle
}

Cum essem parvulus, loquebar ut parvulus, sapiebam ut parvulus, cogitabam ut parvulus. Quando factus sum vir, evacuavi quae erant parvuli.

(I Cor. 13:11)

La maggiore parte de li uomini vivono secondo senso e non secondo ragione, a guisa di pargoli.

(Conv. III.iv.3 $)^{2}$

1. Introduction: Protestantism and the protestant principle - preliminary considerations. 2. The Dantean protest: patterns of sacramentalism (Dante, grace and the historical encounter) and superintendence (Dante, episcopacy and selfepiscopacy). 3. Conclusion: ecclesiality, existentiality and the whereabouts of the Dantean protest.

The first thing to say, lest the reader be tempted to pass by on the other side, is that what follows in this essay has nothing to do with fashioning from Dante a protestant in anything like the most obvious sense of the term, with making of him a sixteenth-century reformer avant la lettre. ${ }^{3}$ On the contrary, it is a question of looking beneath and beyond protestantism in any of its historical manifestations to discern as far as may be something of what Paul Tillich - attuned as he was to the restiveness of Christianity vis-à-vis its own formalities - used to call the protestant principle; so, for example, this from the Protestant Era on the

1 When I was a child, I spake as a child, I understood as a child, I thought as a child; but when I becam a man, I put away childish things $(A V)$.

2 The greater part of mankind live according to sense rather than reason, like children.

3 On protestant readings and appropriations of Dante, E. Moore, 'Dante as a Religious Teacher', in Studies in Dante. Second Series (Miscellaneous Essays) (Oxford: Clarendon Press, 1899; reprint 1968), pp. 1-78 (especially pp. 7-8); A. Valensin, Le Christianiome de Dante (Paris: Aubier, 1954), pp. 15-16. See too M. Caesar (ed.), Dante. The Critical Heritage (London and New York: Routledge, 1989). 
distinction to be drawn between the institutional expression of the idea and the idea itself, the idea by which the institution is at once authorized from deep within itself and by which it is called to account:

Protestantism has a principle that stands beyond all its realizations. It is the critical and dynamic source of all protestant realizations, but it is not identical with any of them. It cannot be confined by a definition. It is not exhausted by any historical religion; it is not identical with the structure of the Reformation or early Christianity or even with a religious form at all. It transcends them as it transcends any cultural form. On the other hand, it can appear in all of them; it is a living, moving, restless power in them; and this is what it is supposed to be in a special way in historical protestantism. The protestant principle, in name derived from the protest of the 'protestants' against decisions of the Catholic majority, contains the divine and human protest against any absolute claim made for a relative reality, even if this claim is made by a protestant church. The protestant principle is the judge of every religious and cultural reality, including the religion and culture which calls itself 'protestant'.

The protestant principle, the source and judge of protestantism, is not to be confused with the 'Absolute' of German idealism or with the 'Being' of ancient and recent philosophy. It is not the highest ontological concept derived from an analysis of the whole of being; it is the theological expression of the true relation between the unconditional and the conditioned or, religiously speaking, between God and man. As such, it is concerned with what theology calls 'faith', namely, the state of mind in which we are grasped by the power of something unconditional which manifests itself to us as the ground and judge of our existence. The power of grasping us in the state of faith is not a being beside others, not even the highest; it is not an object among objects, not even the greatest; but it is a quality of all beings and objects, the quality of pointing beyond themselves and their finite existence to the infinite, inexhaustible, and unapproachable depth of their being and meaning. The protestant principle is the extension of this relationship. It is the guardian against the attempts of the finite and conditioned to usurp the place of the unconditional in thinking and acting. It is the prophetic judgment against religious pride, ecclesiastical arrogance, and secular self-sufficiency and their destructive consequences. ${ }^{4}$

${ }^{4}$ Paul Tillich, The Protestant Era, trans. J. L. Adams (London: Nisbet, 1951), pp. 239-40; cf., idem, Systematic Theology, Part II. Being and God (London: SCM Press, 1978; originally 1951), p. 227: 'The Protestant principle is the restatement of the prophetic principle as an attack against a self-absolutizing and, consequently, demonically distorted church.' 
to which, as similarly alert to the ideal transparency of the historically conditional in the life of the Church to the eternally unconditional, and to this as the main business of theology, we may add these lines - more than ever Tillichian in their combination of power and precision - from his Theology of Culture:

The criterion of every concrete expression of our ultimate concern is the degree to which the concreteness of the concern is in unity with its ultimacy. It is the danger of every embodiment of the unconditional element, religious and secular, that it elevates something conditioned, a symbol, an institution, a movement as such to ultimacy. This danger was well known to the religious leaders of all types, and the whole work of theology can be summed up in the statement that it is the permanent guardian of the unconditional against the aspiration of its own religious and secular appearances. ${ }^{5}$

Thus to live with the protestant principle is to review in respect of their power to new life every received and accredited emphasis in the areas of moral, social, cultural and - as the encompassing of all these things - religious concern. In all these areas, Tillich thinks, it is a question of rethinking every settled habit of mind in respect of its accountability to the agapeic and thus subversive substance of the gospel kerygma, its extraordinary capacity for turning things on their head. This, then, is what Tillich has in mind when he speaks of the protestant principle. What he has in mind is the kind of discerning originating with Christ himself and present to his Church as that whereby it is saved from the demonic possibilities of its own historical forms.

2. Given the challenge mounted by Christianity to each of its successive solutions in the historical order, where, then, is the 'protest' in Dante? In reply to this, we cannot, alas, look to his critique of the contemporary

${ }^{5}$ The Theology of Culture, ed. R. C. Kimball (London, Oxford and New York: Oxford University Press, 1980; originally 1959), p. 29. Similarly in The Protestant Era cit. (previous note), p. 246: 'In the power of the protestant principle, protestantism must fight not only against other ideologies but also against its own. It must reveal the "false consciousness" wherever it hides. It must show how the "man-made God" of Catholicism was in the interest of the feudal order, of which the medieval church was part; how the ideology of Lutheranism was in the interest of the patriarchal order, with which Lutheran orthodoxy was associated; how the idealistic religion of humanistic protestantism is in the interest of a victorious bourgeoisie. The creation of these ideologies - religiously speaking, idols - representing man's will to power, occurs unconsciously. It is not a conscious falsification or a political lie. If this were the case, ideologies would not be very dangerous. But they are dangerous precisely because they are unconscious and are therefore objects of belief and fanaticism. To reveal these concrete ideologies is one of the most important functions of the protestant principle, just as it was one of the main points in the attack of the prophets on the religious and social order of their times.' 
Church in what appears to him to be its lovelessness, for this is a critique inaugurated and sustained, not from beyond, but from within, his general ecclesiology, from out of a prior and settled sense of what the Church actually is. ${ }^{6}$ What, then, for Dante, is the Church? The Church, he thinks, is nothing but the continuing presence of Christ to us under the conditions of time and space, its responsibility, therefore, being that of caring for the flock by way (a) of a faithful proclamation of the gospel message, and (b) of an integral administration of the keys as the power to discernment and to absolution made over to Peter by Christ in the Matthean commission; thus on the life of Christ as the intelligible form of the Church and on the role of the pope as pastor, this passage (xv.2-3) from the third book of the Monarchia:

Ad evidentiam autem minoris sciendum quod natura Ecclesie forma est Ecclesie: nam, quamvis natura dicatur de materia et forma, per prius tamen dicitur de forma, ut ostensum est in Naturali auditu [Physics II. i]. Forma autem Ecclesie nichil aliud est quam vita Cristi, tam in dictis quam in factis comprehensa: vita enim ipsius ydea fuit et exemplar militantis Ecclesie, presertim pastorum, maxime summi, cuius est pascere agnos et oves. ${ }^{7}$

while on the integral preaching of the word, these lines (103-17) from Paradiso XXIX:

${ }^{6}$ On Dante's critique of the contemporary Church, G. Cattani, 'Il sacro zelo di San Pier Damiani a sostegno del sacro zelo di Dante nell'invettiva religiosa della Commedia (Par. c. XXI)', in San Pier Damiani. Atti del Convegno di studi nel IX centenario della morte (Florence: Società Torricelliana di Scienze e Lettere, 1973), pp. 43-59; K. Foster, O.P., 'The Canto of the Damned Popes, Inferno XIX', in The Two Dantes and Other Studies (London: Darton, Longman and Todd, 1977), pp. 86-106; A. Comollo, 'Il topos della corruzione della Chiesa nella Commedia e negli autori cattolici del tempo', in Il dissenso religioso in Dante (Florence: Olschki, 1990), pp. 79-104 (with a number of essays bearing on this subject); E. Airava, 'I papi buoni e cattivi nella Divina Commedia', Settentrione. Rivista di Studi Italo-Finlandesi, n.s. 3 (1996), 115-26; A. Lanza, 'I falsi pastori della Chiesa di Roma', in Dante all'inferno. I misteri eretici della Commedia (Rome: Tre Editori. 1999), pp, 143-55; N. Enright, 'Dante and the Scandals of a Beloved Church', Logos. A Journal of Catholic Thought and Culture 7 (2004), 4, 17-36; R. Imbach, 'Zum Heil der Welt, die übel lebt. Dantes Kirchenkritic und ihre Bedeutung', in Die Kirchenkritic der Mystiker. Prophetie aus Gottesfahrung. I. Mittelalter, ed. M. Delgado et al. (Fribourg-Stuttgart: Academic Press Fribourg-Kohlhammer, 2004), pp. 273-83; I. Castiglia, 'La lupa e l'orsa. L'invettiva contro il “clericus carnalis" nel Canto XIX dell'Inferno', Dante. Rivista internazionale distudi su Dante Alighieri 7 (2010), 35-55.

7 To clarify the minor premiss it must be borne in mind that the church's nature is the form of the church; for although 'nature' is used with reference to matter and to form, nonetheless it refers first and foremost to form, as is shown in the Physics. Now the 'form' of the church is simply the life of Christ, including both his words and his deeds; for his life was the model and exemplar for the church militant, especially for the pastors, and above all for the supreme pastor, whose task is to feed the lambs and the sheep. 
Non ha Fiorenza tanti Lapi e Bindi quante sì fatte favole per anno in pergamo si gridan quinci e quindi: sì che le pecorelle, che non sanno, tornan del pasco pasciute di vento, e non le scusa non veder lo danno.

Non disse Cristo al suo primo convento: 'Andate, e predicate al mondo ciance'; ma diede lor verace fondamento;

e quel tanto sonò ne le sue guance, sì ch'a pugnar per accender la fede de l'Evangelio fero scudo e lance.

Ora si va con motti e con iscede a predicare, e pur che ben si rida, gonfia il cappuccio e più non si richiede. ${ }^{8}$

and, on the power of the keys and Peter's injunction to admit the contrite in spirit, these (lines115-29) from Purgatorio IX:

Cenere, o terra che secca si cavi, d'un color fora col suo vestimento; e di sotto da quel trasse due chiavi.

L'una era d'oro e l'altra era d'argento; pria con la bianca e poscia con la gialla fece a la porta sì, ch'i' fu' contento.

"Quandunque l'una d'este chiavi falla, che non si volga dritta per la toppa", diss' elli a noi, "non s'apre questa calla.

Più cara è l'una; ma l'altra vuol troppa d'arte e d'ingegno avanti che diserri, perch' ella è quella che 'l nodo digroppa.

Da Pier le tegno; e dissemi ch'i' erri anzi ad aprir ch'a tenerla serrata, pur che la gente a' piedi mi s'atterri."

${ }^{8}$ Florence has not so many Lapos and Bindos as fables such as these that are shouted the year long from the pulpits on every side; so that the poor sheep, who know naught, return form the pasture fed with wind - and not seeing the harm does not excuse them. Christ did not say to his first company, "Go and preach idle stories to the world", but he gave them the true foundation; and that alone sounded on their lips, so that to fight for kindling of the faith they made shield and lance of the gospel. Now men go forth to preach with jests and with buffooneries, and so there be only a good laugh, the cowl puffs up and nothing more is asked.

${ }^{9}$ Ashes, or earth that is dug out dry, would be of one colour with his vesture, and from beneath it he drew two keys, the one of gold and the other of silver. First with the white 
Here, though, we need to be careful, for committed as it is to the care of Peter and to those standing in the line of Petrine descent, the Church as but the body of Christ in its continuing presence to us is committed to one whose authority is not that of Christ himself, but of a delegate and appointee. On the one hand, then, these passages from the Monarchia (III.iii.7 and III. vii.4-8) on equivalence and non-equivalence in the area of proper authority:

Summus nanque Pontifex, domini nostri Iesu Cristi vicarius et Petri successor, cui non quicquid Cristo sed quicquid Petro debemus, zelo fortasse clavium, necnon alii gregum cristianorum pastores, et alii quos credo zelo solo matris Ecclesie promoveri, veritati quam ostensurus sum de zelo forsan ut dixi non de superbia contradicunt ... Et si quis instaret de vicarii equivalentia, inutilis est instantia; quia nullus vicariatus, sive divinus sive humanus, equivalere potest principali auctoritati: quod patet de levi. Nam scimus quod successor Petri non equivalet divine auctoritati saltem in operatione nature: non enim posset facere terram ascendere sursum, nec ignem descendere deorsum per offitium sibi commissum. Nec etiam possent omnia sibi commicti a Deo, quoniam potestatem creandi et similiter baptizandi nullo modo Deus commictere posset, ut evidenter probatur, licet Magister contrarium dixerit in quarto. Scimus etiam quod vicarius hominis non equivalet ei, quantum in hoc quod vicarius est, quia nemo potest dare quod suum non est. Auctoritas principalis non est principis nisi ad usum, quia nullus princeps se ipsum auctorizare potest; recipere autem potest atque dimictere, sed alium creare non potest, quia creatio principis ex principe non dependet. Quod si ita est, manifestum est quod nullus princeps potest sibi substituere vicarium in omnibus equivalentem: qua re instantia nullam efficaciam habet. ${ }^{10}$

and then with the yellow he did so to the gate that I was content. "Whenever one of these keys fails so that it does not turn rightly in the lock", he said to us, "this passage does not open. The one is more precious; but the other requires great skill and wisdom before it will unlock, for this is the one that disentangles the knot. From Peter I hold them, and he told me to err rather in opening than in keeping shut, if but the people prostrate themselves at my feet". Otherwise on the power of the keys, Mon. III.i.5: 'et queritur utrum auctoritas Monarche romani, qui de iure Monarcha mundi est, ut in secundo libro probatum est, inmediate a Deo dependeat an ab aliquo Dei vicario vel ministro, quem Petri successorem intelligo, qui vere claviger est regni celorum'; Inf. XIX.100105; XXVII.100-105; Par. XXIII.136-39; XXIV. 34-39; XXVII.46-51; XXXII.124-26, etc. P. Armour, The Door of Purgatory. A Study of Multiple Symbolism in Dante's 'Purgatorio' (Oxford: Clarendon Press, 1983), pp. 76-99; C. Ross, 'Canto IX. The Ritual Keys', in Lectura Dantio. Purgatorio, ed. A. Mandelbaum et al. (Berkeley, Los Angeles and London: University of California Press, 2008), pp. 85-94.

${ }^{10}$ For the supreme Pontiff, the vicar of our Lord Jesus Christ and Peter's successor, to whom we owe not what is due to Christ but what is due to Peter, perhaps motivated by a zealous concern for the keys, and with him other shepherds of the Christian flock and 
while on the other, these (III.xvi.10 and 15) from the final moments of the book on the status of imperial no less than of papal office as a product of divine intentionality:

Propter quod opus fuit homini duplici directivo secundum duplicem finem: scilicet summo Pontifice, qui secundum revelata humanum genus perduceret ad vitam ecternam, et Imperatore, qui secundum phylosophica documenta genus humanum ad temporalem felicitatem dirigeret ... Sic ergo patet quod auctoritas temporalis Monarche sine ullo medio in ipsum de fonte universalis auctoritatis descendit: qui quidem fons, in arce sue simplicitatis unitus, in multiplices alveos influit ex habundantia bonitatis. ${ }^{11}$

It is, then, from out of a sense of the Church thus understood, as that whereby man is confirmed in his ultimate happiness in and through God's provision for him by way of the Christ and of those commissioned by the Christ in expectation of his coming again, that Dante embarks on his litany of indictment; so, for example, the 'I' non so s' i' mi fui qui troppo folle' passage of Inf. XIX.88-105 on clerical greed and on the blasphemy thereof:

others who I believe act only out of zealous concern for Mother Church: these people oppose the truth I am about to demonstrate - perhaps, as I said, out of zealous concern and not out of pride ... And if anyone were to base an objection on a vicar's being equivalent, the objection has no force, for no vicariate, human or divine, can be equivalent to the primary authority; and this is easy to see. For we know that Peter's successor is not the equivalent of divine authority at least as regards the workings of nature, for he could not make earth rise nor fire descend by virtue of the office entrusted to him. Nor could all things be entrusted to him by God, since God certainly could not entrust to him the power to create and the power to baptize, as is quite apparent, although Peter Lombard expressed the contrary opinion in his fourth book. We also know that a man's vicar, in as much as he is his vicar, is not equivalent to him, because no one can give away what does not belong to him. A prince's authority belongs to a prince only as something for his use, for no prince can confer authority on himself; he can accept it and renounce it, but he cannot create another prince, for the creation of a prince is not dependent on a prince. If this is the case, it is clear that no prince can appoint a vicar to take his place who is equivalent to him in all things; thus the objection has no force.

${ }^{11}$ It is for this reason that man had need of two guides corresponding to his twofold goal: that is to say the supreme Pontiff, to lead mankind to eternal life in conformity with revealed truth, and the Emperor, to guide mankind to temporal happiness in conformity with the teachings of philosophy ... Thus it is evident then that the authority of the temporal monarch flows down into him without any intermediary from the fountainhead of universal authority; this fountainhead, though one in the citadel of its own simplicity of nature, flows into many streams from the abundance of his goodness. On the precise relationship of imperial and philosophical authority as twin co-efficients in respect of the happiness of this life (the 'secundum phylosophica documenta' of III.xvi.10), J. Took, “Diligite iustitiam qui iudicatis terram": Justice and the Just Ruler in Dante', in Dante and Governance, ed. J. R. Woodhouse (Oxford: Oxford University Press, 1997), pp. 137-51. 
Io non so s'i' mi fui qui troppo folle, ch'i' pur rispuosi lui a questo metro: "Deh, or mi dì: quanto tesoro volle

Nostro Segnore in prima da san Pietro ch'ei ponesse le chiavi in sua balìa? Certo non chiese se non 'Viemmi retro'.

Né Pier né li altri tolsero a Matia oro od argento, quando fu sortito al loco che perdé l'anima ria.

Però ti sta, ché tu se' ben punito; e guarda ben la mal tolta moneta ch'esser ti fece contra Carlo ardito.

$\mathrm{E}$ se non fosse ch'ancor lo mi vieta la reverenza de le somme chiavi che tu tenesti ne la vita lieta, io userei parole ancor più gravi; ché la vostra avarizia il mondo attrista, calcando i buoni e sollevando i pravi”."12

or the 'tosto libere fien de l'avoltero' passage of Par. IX.133-42 on the Church's desertion the Nazarene in favour of the decretalists:

\author{
Per questo l'Evangelio e i dottor magni \\ son derelitti, e solo ai Decretali \\ si studia, sì che pare a' lor vivagni. \\ A questo intende il papa e ' cardinali; \\ non vanno i lor pensieri a Nazarette, \\ là dove Gabrïello aperse l'ali. \\ Ma Vaticano e l'altre parti elette \\ di Roma che son state cimitero \\ a la milizia che Pietro seguette, \\ tosto libere fien de l'avoltero. ${ }^{13}$
}

${ }^{12}$ I do not know if here I was overbold, in answering him in just this strain: "Pray now tell me how much treasure did our Lord require of St Peter before he put the keys into his keeping? Surely he asked nothing save 'Follow me'. Nor did Peter or the others take gold or silver of Matthias when he was chosen for the office which the guilty soul had lost. Therefore stay right here, for you are justly punished; and guard well the ill-got gain that made you bold against Charles. And were it not that reverence for the great keys which you held in the glad life even now forbids it to me, I would use yet harder words, for your avarice afflicts the world, trampling down the good and exalting the poor."

${ }^{13}$ For this the gospel and the great doctors are deserted, and only the decretals are studied, as may be seen from their margins. Thereon the pope and the cardinals are intent. Their thoughts go not to Nazareth whither Gabriel spread his wings. But the Vatican and the other chosen parts of Rome which have been the burial place for the soldiery that followed Peter shall soon be free from this adultery. 
or the 'il luogo mio, il luogo mio, il luogo mio' passage of Par. XXVII.16-27 on the stench of ecclesiastical corruption:

La provedenza, che quivi comparte vice e officio, nel beato coro silenzio posto avea da ogne parte, quand' io udi': "Se io mi trascoloro, non ti maravigliar, ché, dicend' io, vedrai trascolorar tutti costoro.

Quelli ch'usurpa in terra il luogo mio, il luogo mio, il luogo mio, che vaca ne la presenza del Figliuol di Dio, fatt' ha del cimitero mio cloaca del sangue e de la puzza; onde 'l perverso che cadde di qua sù, là giù si placa". ${ }^{14}$

For Dante, then, papacy, piracy and profligacy - indeed papacy, piracy and prostitution (the 'puttana sciolta' passage of Purg. XXXII.148-60) ${ }^{15}$ flow one into the other, reinforcing as they do so their joint capacity for scandalizing the pious spirit. But - and this now is the point - Dante's, for all the strength of its indictment, is a discourse contained by, rather than challenging, his ecclesiology, his sense of the Church in its hierocracy, its apostolicity and its sacramentality. None of this is at stake. What is at stake is not the idea, but the practicality of it all, the maladministration by those entrusted with it, of Christ's substance and legacy.

If not here, then, where $i s$ the Dantean protest, that element of restiveness and of rethinking marking him out as a Christian poet and prophet? The answer is twofold, Dante's being a sense $(a)$ of the cultural encounter generally, as distinct from the ecclesiastical encounter in particular, as a channel of grace, and (b) of episcopacy as, whatever else it is, a matter of self-episcopacy, of self-oversight on the plane of properly human being and doing, these things between them making for an opening-out of the

14 The providence which there assigns turn and office had imposed silence on the blessed choir on every side, when I heard, "If I change colour, marvel not, for, as I speak, you shall see all these change colour. He who on earth usurps my place, my place, my place, which in the sight of the Son of God is vacant, has made my burial-ground a sewer of blood and of stench, so that the perverse one who fell from here above takes comfort there below".

${ }^{15}$ [Secure, like a fortress on a high mountain, there appeared to me] an ungirt harlot [sitting upon it, with eyes quick to rove around]. The passage in its entirety runs as follows: 'Sicura, quasi rocca in alto monte, / seder sovresso una puttana sciolta / mapparve con le ciglia intorno pronte; / e come perché non li fosse tolta, / vidi di costa a lei dritto un gigante; / e basciavansi insieme alcuna volta. / Ma perché l'occhio cupido e vagante / a me rivolse, quel feroce drudo / la flagellò dal capo infin le piante; / poi, di sospetto pieno e d'ira crudo, / disciolse il mostro, e trassel per la selva, / tanto che sol di lei mi fece scudo / a la puttana e a la nova belva.' 
ecclesiastical upon the existential, upon existence itself, in all the myriad determinacy of existence, as enlisted and empowered as a means of divine purposefulness. To take then, the first of these things - the status of the cultural encounter generally, as distinct from the ecclesiastical encounter in particular, as a means of grace - we may begin by noting that references in the Commedia to the sacraments, even to the sacraments of baptism and the eucharist, are few and far between and, as often as not, either allusive or parodistic; ;6 so, for example, as regards baptism, the 'cleansing with the reed' episode of Purg. I.94-99 and 130-36 or the Lethe and Eunoè episodes of Purg. XXXI.91-105 and XXXIII.127-45, and, as regards the eucharist, the cases of Ugolino and of Lucifer, each alike suggestive of the substance and significance of the sacrament in question, but at an imaginative remove, indirectly rather than in any sense systematically. How, then, are we to account for this situation? By way not so much of the attenuated importance of these things in a discourse of anagogical inspiration (the sacramental phase of the religious life now slipping into the past), but of a preoccupation in Dante with the encounter itself, in all the incarnational intensity of the encounter, as a means of grace and principle of salvation. This at any rate, or something close to it, is the implication of the Virgilian and the Beatrician moment of the text, each alike present to him as soteriologically significant; on the one hand, then, as regards the Virgilian moment, these lines (4054) from Canto XXX of the Purgatorio, secure in their sense of the salvific substance of it all, of the encounter itself as the way of emergence:

Tosto che ne la vista mi percosse l'alta virtù che già m'avea trafitto prima ch'io fuor di püerizia fosse, volsimi a la sinistra col respitto col quale il fantolin corre a la mamma quando ha paura o quando elli è afflitto, per dicere a Virgilio: 'Men che dramma di sangue m’è rimaso che non tremi:

16 To the fore among Dante's references to baptism, Inf. IV.31-36 and Par. XXV.1-12 on baptism as the 'portal of faith' (Inf. IV.36), Par. XXXII.76-84 on baptism as confirmation of being in Christ, and Par. XX.127-29 on the baptism of grace preceding baptism proper by a thousand years ('Quelle tre donne li fur per battesmo / che tu vedesti da la destra rota, / dinanzi al battezzar più d'un millesmo'). On marriage, after Matt. 22:30 and in addition (but metaphorically) to the Neque nubent of Purg. XIX.136-38, Inf., XIX.1-4, Par. X.139-44, XI.55-66 and XXXI.1-3. On ordination, and apart from the 'sommo officio' and 'ordini sacri' moment of Inf. XXVII.85-93 (itself scarcely systematic), the crowning and mitring moment of Purg. XXVII ult. (but see below on this passage). P. Armour, The Door of Purgatory. A Study of Multiple Symbolism in Dante's 'Purgatorio' (note 9 above), pp. 5 ff.; E. Ardissino, 'La storia dell'eterno e il rinnovamento battesimale del poeta', in Tempo liturgico e tempo storico nella “Commedia" di Dante (Città del Vaticano: Libreria Editrice Vaticana, 2009), pp. 89-108. 
conosco i segni de l'antica fiamma'.

Ma Virgilio n'avea lasciati scemi

di sé, Virgilio dolcissimo patre,

Virgilio a cui per mia salute die'mi;

né quantunque perdeo l'antica matre,

valse a le guance nette di rugiada,

che, lagrimando, non tornasser atre. ${ }^{17}$

while on the other, and as far now as the Beatrician moment of his experience is concerned, these (lines 70-93) from Canto XXXI of the Paradiso, similarly committed to the status of the encounter, in all the particularity of the encounter, as the in-and-through-which of new life:

Sanza risponder, li occhi sù levai,

e vidi lei che si facea corona

reflettendo da sé li etterni rai.

Da quella regïon che più sù tona

occhio mortale alcun tanto non dista,

qualunque in mare più giù s'abbandona,

quanto lì da Beatrice la mia vista;

ma nulla mi facea, ché süa effige

non discendëa a me per mezzo mista.

"O donna in cui la mia speranza vige,

e che soffristi per la mia salute

in inferno lasciar le tue vestige,

${ }^{7}$ As soon as on my sight the lofty virtue smote that had already pierced me before I was out of my boyhood, I turned to the left with the confidence of a little child that runs to his mother when he is frightened or in distress, to say to Virgil, "Not a drop of blood is left in me that does not tremble: I know the tokens of the ancient flame". But Virgil had left us bereft of himself, Virgil sweetest father, Virgil to whom I gave myself for my salvation; nor did all that our ancient mother lost keep my dew-washed cheeks from turning dark again with tears. See too as regards the soteriological significance of the Virgilian moment of his experience in the case now of Statius, the 'Per te poeta fui, per te cristiano' moment of Purg. XXII.55-75: “'Or quando tu cantasti le crude armi / de la doppia trestizia di Giocasta", / disse 'l cantor de' buccolici carmi, / "per quello che Clï̀ teco lì tasta, / non par che ti facesse ancor fedele / la fede, sanza qual ben far non basta. / Se così è, qual sole o quai candele / ti stenebraron sì, che tu drizzasti / poscia di retro al pescator le vele?". / Ed elli a lui: “Tu prima m'invïasti / verso Parnaso a ber ne le sue grotte, / e prima appresso Dio malluminasti. / Facesti come quei che va di notte, / che porta il lume dietro e sé non giova, / ma dopo sé fa le persone dotte, / quando dicesti: 'Secol si rinova; / torna giustizia e primo tempo umano, / e progenïe scende da ciel nova'. / Per te poeta fui, per te cristiano: / ma perché veggi mei ciò ch"io disegno, / a colorare stenderò la mano"'. T. Barolini, Dante's Poets. Textuality and Truth in the Comedy (Princeton, N.J.: Princeton University Press, 1984), especially pp. 256-69; G. Brugnoli, 'Statius christianus', Italianistica 17 (1988), 1, 9-15; C. Kallendorf and H. Kallendorf, "Per te poeta fui, per te cristiano" (Purg. 22.73). Statius as Christian, from "Fact" to "Fiction"', Deutsches Dante-Jabrbuch 77 (2002), 61-72; P. M. Clogan, 'Dante and Statius: Revisited', Medievalia et Humanistica 35 (2009), 77-101. 
di tante cose quant' i' ho vedute, dal tuo podere e da la tua bontate riconosco la grazia e la virtute.

Tu m'hai di servo tratto a libertate per tutte quelle vie, per tutt' i modi che di ciò fare avei la potestate.

La tua magnificenza in me custodi, sì che l'anima mia, che fatt' hai sana, piacente a te dal corpo si disnodi”.

Così orai; e quella, sì lontana come parea, sorrise e riguardommi; poi si tornò a l'etterna fontana. ${ }^{18}$

Now grace, as nothing other than the extrinsication or outpouring of the love-substance of the Godhead, everywhere abounds in the Commedia, and everywhere abounds as the prior and perpetual condition of man's proper homecoming as man, as that whereby, in and through the love-solicitude of the Father, he lays hold of the deiformity or Godlikeness to which he is called from beforehand. But within the economy of the Commedia as an account of the 'indiarsi' or in-Godding of self as the final cause of every significant inflexion of the spirit, grace thus understood, as nothing but the overflowing of divine goodness in ever new channels of creative and recreative concern, is mediated as much by the encounter as by the forms and formularies of the Church, at which point ecclesiology gives way to something closer to a theology of culture as a way of seeing and setting up the soteriological issue. Emphatically, nothing is lost here ecclesiologically, for Dante's, in the Commedia, is a rejoicing both in the unspeakable sweetness of the liturgical moment and in the refined substance of prayer under the aspect both of praise and of intercession. ${ }^{19}$ But for all that, the journey into

18 Without answering I lifted up my eyes and saw her where she made for herself a crown as she reflected the eternal rays. From the region which thunders most high no mortal eye is so distant, were it plunged most deep within the sea, as there from Beatrice was my sight. But to me it made no difference, for her image came down to me unblurred by aught between. "O lady in whom my hope is strong, and who for my salvation did endure to leave in hell your footprints, all those things which I have seen I acknowledge the grace and the virtue to be from your power and your excellence. It is you who have drawn me from bondage into liberty by all those paths, by all those means by which you had the power so to do. Preserve in me your great munificence, so that my soul which you have made whole, may be loosed from the body, pleasing unto you." So did I pray; and she, so distant as she seemed, smiled and looked on me, then turned again to the eternal fountain.

19 J. C. Barnes, 'Vestiges of the Liturgy in Dante's Verse', in Dante and the Middle Ages, ed. J. C. Barnes and C. Ó Cuilleanáin (Dublin: Irish Academic Press, 1995), pp. 231270; E. Alberione, 'Liturgie della speranza nel Purgatorio dantesco', in Purgatorio (Milan: San Fedele, 1996), pp. 54-67; R. L. Martinez, 'L'“amoroso canto”. Liturgy and Vernacular 
God is existentially rather than ecclesially conceived, effected by way, not of the strange semiosis of the sacrament, but of the sacredness of the event itself in all its power to persuade from out of its innermost recesses.

But with what amounts to a sense in Dante of the salvific status of the encounter generally we are still in the foothills where his version of the protest is concerned, for more impressive still is his fashioning from the idea of episcopacy something closer to self-episcopacy as the goal of moral and ontological aspiration. Now this too needs careful statement, for if on the one hand to be as man is to be in and through the power properly one's own to moral self-determination, then there can, on the other, be no dispensing with the kind of episcopal oversight whereby self is encouraged and sustained from beyond self as a pilgrim spirit; so, for example, these lines from Paradiso V (73-78) with their commitment, not only to Scripture, but to pastoral care as the way of salvation:

Siate, Cristiani, a muovervi più gravi: non siate come penna ad ogne vento, e non crediate ch'ogne acqua vi lavi.

Avete il novo e 'l vecchio Testamento, e 'l pastor de la Chiesa che vi guida; questo vi basti a vostro salvamento. ${ }^{20}$

or these (lines 13-18) from the next canto on the place of the priest and above all of the Pope as pastor to the perplexed:

Lyric in Dante's Purgatorio', Dante Studies 127 (2009), 93-127; idem, 'Place and Times of the Liturgy from Dante to Petrarch', in Petrarch and Dante. Anti-dantiom, Metaphysics, Tradition, ed. Z. G. Barański (Notre Dame: Notre Dame University Press, 2009), pp. 320-370. On prayer and prayerfulness, E. Auerbach, 'La preghiera di Dante alla Vergine (Par. XXXIII) ed antecedenti elogi', in Studisu Dante (Milan: Feltrinelli, 1984), pp. 273-308; N. Costanzo, 'I versi 1-21 della preghiera alla Vergine. Ipotesi di rilettura', in L'Alighieri. Rassegna bibliografica Jantesca 28 (1987), 2, 26-47 (and in Curiosità del ritmo poetico (Pasian di Prato: Campanotto, 2003), pp. 31-65); A. Vallone, 'Par. XXXIII: la preghiera, l'uso della scuola e l'insufficienza della parola', in Cultura e mxemoria in Dante (Naples: Guida, 1988), pp. 59-119; F. Salsano, 'Nella preghiera alla Vergine un percorso melodico. Considerazioni sul Canto XXXIII del Paradiso', in L'Osservatore Romano, 8 dicembre (1991), p. 3 (with a revised version entitled 'Canto XXXIII', in Lecturae Dantis (Ravenna: Longo 2003), pp. 242-53); G. Barberi Squarotti, 'La preghiera alla Vergine: Dante e Petrarca', Filologia e Critica 20 (1995), 2-3, 365-74 (subsequently in Il tragico cristiano da Dante ai moderni (Florence: Olschki, 2003), pp. 87-95); P. A. Perotti, 'La preghiera alla Vergine (Par. XXXIII.1-39)', in LiAlighieri. Rassegna bibliografica dantesca 36 (1995), 6, 75-83; R. Migliorini Fissi, 'La preghiera alla Vergine (Paradiso XXXIII, vv. 1-39)', in Archivio Perugino-Pievese, 3 (2000), 1, 115-33; R. Scrivano, 'Superbia, umiltà e preghiera in Purgatorio XI', in Esperienze Letterarie 31 (2006), 3, 3-19.

${ }^{20}$ Be graver, you Christians, in moving. Be not like a feather to every wind, and think not that every water may cleanse you. You have the New Testament and the Old, and the shepherd of the Church, to guide you. 
E prima ch'io a l'ovra fossi attento, una natura in Cristo esser, non piùe, credea, e di tal fede era contento;

ma 'l benedetto Agapito, che fue sommo pastore, a la fede sincera mi dirizzò con le parole sue. ${ }^{21}$

or these from the Monarchia at III.xv.3 on feeding the sheep as the very stuff of the Church Militant:

Forma autem Ecclesie nichil aliud est quam vita Cristi, tam in dictis quam in factis comprehensa : vita enim ipsius ydea fuit et exemplar militantis Ecclesie, presertim pastorum, maxime summi, cuius est pascere agnos et oves. ${ }^{22}$

Everywhere, then, it is a question of priestly oversight, of a species of superintendency designed in response to the gospel imperative to ensure the well-being of Christ's flock, to exercise, in short, a duty of care and compassion. But - and this now is what matters - for all the indispensability of shepherding thus understood to any kind of ultimate homecoming, there can be no question of Dante's privileging the heteronomous over the autonomous component of human experience under the conditions of time and space, the regulative over the selfregulative component, for herein - in the power of self to self-governance - lies the ground and guarantee of man's likeness to God as a creature of self-understanding and of self-determination; hence the following passage from Canto XXVII of the Purgatorio designed precisely to confirm and celebrate the entry of the soul into its own company, there to rejoice in the completeness of its regal and episcopal sufficiency:

"Quel dolce pome che per tanti rami cercando va la cura de' mortali, oggi porrà in pace le tue fami”.

Virgilio inverso me queste cotali parole usò; e mai non furo strenne che fosser di piacere a queste iguali.

Tanto voler sopra voler mi venne

${ }^{21}$ And before I had put my mind to this work, one nature and no more I held to be in Christ, and with that faith I was content; but the blessed Agapetus, who was the supreme pastor, directed me to the true faith by his words.

${ }^{22}$ Now the form of the Church is simply the life of Christ, including both his words and his deeds; for his life was the model and exemplar for the Church Militant, especially for the pastors, and above all for the supreme pastor, whose task is to feed the lambs and the sheep. John 21:15-17. 
de l'esser sù, ch'ad ogne passo poi

al volo mi sentia crescer le penne.

Come la scala tutta sotto noi

fu corsa e fummo in su 'l grado superno,

in me ficcò Virgilio li occhi suoi,

e disse: "Il temporal foco e l'etterno

veduto hai, figlio; e se' venuto in parte

dov' io per me più oltre non discerno.

Tratto t'ho qui con ingegno e con arte;

lo tuo piacere omai prendi per duce;

fuor se' de l'erte vie, fuor se' de l'arte.

Vedi lo sol che 'n fronte ti riluce;

vedi l'erbette, i fiori e li arbuscelli

che qui la terra sol da sé produce.

Mentre che vegnan lieti li occhi belli

che, lagrimando, a te venir mi fenno, seder ti puoi e puoi andar tra elli.

Non aspettar mio dir più né mio cenno;

libero, dritto e sano è tuo arbitrio,

e fallo fora non fare a suo senno:

per ch"io te sovra te corono e mitrio".

(Purg. XXVII.115-42) $)^{23}$

Predictable as this is as a point of arrival in respect of what amounts in the first two canticles of the Commedia to a song of descents and of ascents on the part of the ontically anxious subject, it comes as a shock to see it in black and white, Dante's in this sense being a radical internalization of every authoritarian structure in the Church, a fashioning from observance and obedience something closer to an inner discipline of the Spirit. If, then, princes and prelates have their part to play in facilitating the process of

23 "That sweet fruit which the care of mortals goes seeking on so many branches, this day shall give your hungering peace." Such were Virgil's words to me, and never were there gifts that could be equal in pleasure to these. Such wish upon wish came to me to be above, that at every step thereafter I felt my feathers growing for the flight. When all the stair was sped beneath us and we were on the topmost step, Virgil fixed his eyes on me and said, "The temporal fire and the eternal you have seen, my son, and are to come to a part where I of myself discern no farther onward. I have brought you here with understanding and with art. Take henceforth your own pleasure for your guide. Forth you are from the steep ways, forth from the narrow. See the sun that shines on your brow, see the tender grass, the flowers, the shrubs, which here the earth of itself alone produces; till the beautiful eyes come rejoicing which weeping made me come to you, you may sit or go among them. No longer expect a word or sign from me. Free, upright, and whole is your will, and it would be wrong not to act according to its pleasure; wherefore I crown and mitre you over yourself". 
properly human being and becoming, dereliction by way either of vacancy or of violence making for catastrophe in the lives of those subject to them, there can, he thinks, be no delivering of self to anything other than its proper power to self-actualization, anything other than this, Dante must have thought, making less for the meat than for the milk of the moral and religious life, for something closer to the adolescent than to the adult as a disposition of the spirit.

3. The first thing to say when it comes to Dante and the protestant principle is that there can be no question of fashioning from him a proto-protestant, a crypto-protestant or any other kind of protestant in any historically determinate sense of the word, Dante's being an understanding of the religious situation generally and of the ecclesiological situation in particular predating both in the letter and in the spirit those of the great divide. On the contrary, both in its sacramentalism and in its sacerdotalism (neither, however, figuring prominently on his horizon of concern) his sense of the Church in respect of what it is and what it does remains a product of contemporary consciousness in all the, as far as he is concerned, unexceptionality of that consciousness. But for all that, and entirely without prejudice to the indispensibility of the rites and observances of the moral and religious life to its stable pursuit and orderly implementation, his is a thinking through of that life in terms, less of its ecclesiality, than of its existentiality, of its rootedness in, and transparency to a consummate act of specifically human being. Thus those same rights and observances, functional in the highest degree as that whereby the spirit knows itself in the rhythm of its journey into God, stand at last to be referred to something at once more profound and more primordial than themselves, at which point the protest - as indispensible to the life of the spirit as its forms and formularies - once again moves into view. 